\title{
Opinion
}

\section{FUTURE OF THE GLOBAL SOUTH: SOME CRITICAL FOREIGN POLICY CONSIDERATIONS}

\author{
Anis H Bajrektarevic \\ International Law \& Global Political Studies, \\ Vienna, Austria \\ anis@corpsdiplomatique.cd
}

\begin{abstract}
Economic downturn, recession of plans and initiatives, systematically ignored calls for a fiscal and monetary justice for all, $€$-crisis, Brexit and irredentism in the UK, Spain, Belgium, France, Denmark and Italy, lasting instability in the Euro-Med theatre (debt crisis of the Europe's south - countries scrutinized and ridiculed under the nickname PIGS, coupled with the failed states all over the MENA), terrorism, historic low with Russia along with a historic trans-Atlantic blow with Trump, influx of predominantly Muslim refugees from Levant in numbers and configurations unprecedented since the WWII exoduses, consequential growth of far-right parties who - by peddling reductive messages and comparisons - are exploiting fears of otherness, that are now amplified with already urging labour and social justice concerns, generational unemployment and socio-cultural anxieties, in ricochet of the Sino-US trade wars, while rifting in a dilemma to either let Bolivarism or support Monroeism. The very fundaments of Europe are shaking. Strikingly, there is a very little public debate enhanced in Europe about it. What is even more worrying is the fact that any self-assessing questioning of Europe's involvement and past policies in the Middle East, and Europe's East is off-agenda. Immaculacy of Brussels and the Atlantic-Central Europe-led EU is unquestionable. Corresponding with realities or complying with a dogma?
\end{abstract}

Keywords: EU, Economic downturn, socio-cultural anxieties, Middle east, Brussels

\section{Introduction}

Both Islam and Christianity lived in harmony (or at least they successfully cohabitated) for centuries within the MENA proper, notably in Lebanon, Syria Egypt and Iraq. Why then there was no harmonious relationship between Christian Europe and the Middle East? Was Europe opting to demonise the Muslims in order to artificially generate a homogenous European self? No enemy at gate, no unity at home?

This is a story of the past centuries - one may say. Still, absence of any self-reflection on the side of the EU towards its policy in the Middle East today, makes it worth to revisit some of the bleak chapters of European history, and the genesis of its pre-secular and secular thoughts. 
Europe came to be known as 'Christendom' because its identity was imagined or invented as the Catholic in contradistinction to the Islamic Middle East and to the Eastern (authentic, true or Orthodox) Christianity. ${ }^{4}$

The Christianity, of course, originated in the Middle East not in Europe. It was subsequently universalised and, by spreading onto peripheral world, Europeanised by the Balkan-born Roman Emperor - Constantin the Great (Edicto de Milan, 313 AD). He himself spent much of his life on Bosporus and hence, was buried in Asia Minor. Surely, it was by the legal design of this glorious Emperor (fully backed by the Empire's political elite) that the city of Rome was (re)turned into an administrative periphery, politico-ideological outcast and geostrategic suburbia (by 324 AD). The official seat of Roman Empire including the Roman Senate - by yet another historic edict of $330 \mathrm{AD}$ - became Constantin-polis (Constantinople), and it remained as such until a very end of the Empire, 11 centuries later.

Therefore, the post Roman/Byzantine inauguration of 'Christendom' as a pure western culture necessitated sustained intellectual acrobatics - starching the truth away from an elementary geography and historical evidence. Such an inversion by which an ideological and geopolitical periphery presents itself as a centre required considerably emasculation - both, physical coercion and imposed narrative over the extensive space and time. ${ }^{5}$

This $a$ 'la card creation of Catholic Christendom or to say; Western Ummah, served two vital objectives: domestic and external. Both helped solidification of the feudal socio-economic and politico-military system and based on that of a precolonial European collective identity. Domestically, it served for a coherent sense of selfhood - us vs. them paradigm: Unity, oppression and obedience. Extra ecclesiam nulla salus - no salvation outside the church, following the old Roman rational 'no world beyond Limes line', or the modern one: 'no prosperity outside the EU'. Externally, here was found the 'moral' narrative - a justifier for the subsequent military voyages and other forms of organized plunders. Such an image build-up, of course, was coupled with a coercive societal identity - the 'Dark ages' for at home, crusaders for abroad.

This is how Europeans started to view the religious conflict as the identifying attribute of the system's formation, while elsewhere on the globe the interethnic and interreligious coexistence was a traditional modus operandi within and among countries.

By the time of Renaissance, Catholic Europe came to realize that, in order to effectively project itself - to physically and/or mentally colonise overseas territories - it needed either coercion (rarefying and assimilation), labour-camp detention (slavery) or final solution (physical extermination). These strategic dilemmas over the instruments to use, influenced and

\footnotetext{
${ }^{4}$ Western animosities towards Russia that are constantly here (with some short-lived exceptions during the Metternich post-Vienna congress period, Bismarck chancellorship and Yeltsin dizzy years) are escaping any rational explanation. The only possible logics to find is if going back to the moment of split of the Christian Church, mid XI century. That is the time when the Roman curia decided to compete with Constantinople by organising the invading tribes in Europe for its 'civilising' mission (read: geostrategic ends), alongside the parallel process that have started with the Russophones undertaking a similar mission in the norther and north eastern portions of Eurasia. Two parallel 'civilising' missions, competing over concept and territories for centuries.

${ }^{5}$ Transferring the official seat of the Roman Empire to Bosporus marked far more than just an event of the peripheral maturity; periphery pressing onto the centre. It meant that - at the peak times of the Milan's Edict of Constantin the Great - the peripheral power successfully relocated itself closer to the centre; ideologically (metaphysically, religiously) but also geopolitically (physically, geographically). Not to insert itself (like during the subsequent Crusaders), but to transcend. That is a real meaning of the transfer of imperial capital from Rome to Bosporus once for good. This will be the first and the last such a successful move from Europe, in human history. With this adjustment - past its failed European experiment, Roman Empire returned to its origins; Balkans and the Middle East, which extended the Empire's life impressively - for over 1,000 years.
} 
dominated European debates of the time. It brought about the conception of the 'noble savage' - who could be assimilated, versus the 'ignoble savage' who was destined for either labour detention or final solution. That coerce-or-exterminate dilemma of 'soul salvationists' even culminated within the pre-Westphalian Christian Ummah. It was best epitomised in the famous Valladolid controversy of 1550, by which Juan Ginés de Sepúlveda's notion of the ignoble savage faced off against Bartolomé de Las Casa's view of the noble savage.

In both cases - the claim was offered - the Amero/AfroAsian Natives deserve salvation as they have a 'strong desire for it', but the views differed on whether the Natives' prone wishes exceeded their mental capacity to receive Christianity. Hence, the debates - which were the roots and origins of the later liberal theories as well as the early precursors to the subsequent regime change, humanitarian intervention and preemption doctrines, and to the (onesided ultimatum of) EU Accession criteria - always presupposed the inferiority (and passivity) of the Natives.

Frankly, this remains a constant behaviour in international relations: E.g. views on Libya differed, as they differ today on Syria. However, what is common to all views is; nobody consults the local population and considers what they would like for themselves. ${ }^{6}$

\section{Legitimizing the imperialism of imagination}

In a course of subsequent centuries, the notion of final solution underwent through a sophistication, and was eventually replaced by the combination of cultural conversions/ submissions (induced submissiveness), politico-military obedience and socio-economic apartheid. A subtle apartheid (that is easy to deny, but hard to prove) is usually better than the brute genocide (which is traceable and easily quantifiable). At the peaks of imperialism a nobleignoble savage dilemma was embodied in an implicit and explicit racism. Debate was focused on a question whether the nations' inferiority can be remedied through the imperial 'civilizing' mission, with social Darwinists and 'scientific' racists being rather pessimistic, but more forthcoming on possible solutions. ${ }^{7}$

The so-called central dilemma of liberalism - Is it liberal to impose liberal values on illiberal societies - was of course only an innocently looking tip of the large iceberg, of the tireless othering. This 'epistemology' was further soft-embedded in the so-called Peter Pan theory with a romanticised image of the Other as more childishly careless and helpless, than intentionally cruel and barbaric. Foreign remained Other, but 'became' rather alluring, promiscuous and exotic. Essentially, the East as a child enveloped in innocence, a derided inferior who would never grow up. This, of course, gave rise to various binary categorisations, the us-vs.them/either-or listings, in order to manufacture rift and hence to facilitate a decisive and longlasting differentiation between the constructed West and the East. ${ }^{8}$

The West as a constructed male vs. the East as a constructed female. A 'mind-oriented' west vs. a 'body-oriented' east. Phallusoid peninsulas and islands of (Atlantic-Scandinavian) Europe

\footnotetext{
${ }^{6}$ For centuries, it follows the same matrix: doctrinated/induced inferiority, denouncing, attack, marginalization, passivation, plunder, indirect rule, remote control presence. Or, reduced to a binary code formula: victimisationcriminalisation. Namely: humanitarian intervention.

${ }^{7}$ E.g. Cecil Rhodes, the $19^{\text {th }}$ century British businessman and the architect of Apartheid, used to say that to be born an Englishman was to have 'won first prize in the lottery of life'. He is also remembered of the following: "I contend that we are the first race in the world, and that the more of the world we inhabit the better it is for the human race." Large part of colonial Africa was called after his name - Rhodesia, until rather recently, 1979.

${ }^{8}$ Small surprise that the $43^{\text {rd }}$ US President (un)famously claimed: 'you are either with us or against us'. His father, the $41^{\text {st }}$ US President, viewed the Cold War and summarised its epilogue effectively: 'We win, they lose'. For the Atlantist's world all should be Kierkegaardian either-or, a binary choice.
} 
vs. womb-like continental landmass of Afro-Asia; Erective and explosive vs. reflective and implosive; an Omnipresent (ever seafaring and trading) extroverted male vs. humble, handcrafting, waiting female. Masculine, phallusoid, progressively erected temporal linearity vs. periodic menstrual leakages of femininity in regressive cycles of stagnation. Clearly, anything beyond that was deemed inconsequential.

Physical, material, ideological, active, polarizing, determined vs. metaphysical, spiritual, esoteric, atmospheric, inclusive, holistic. No wonder that all operationalized ideologies originated solely in Europe. What else, since no one ever, but Asians revealed any significant religion to the world. ${ }^{9}$ Ideology penetrates, religion embraces.

\section{AgitProp - Non-stop}

Gradually, the imperial civilizing mission (Expansion is a path to Security) got a new form, often under the watchful care of 'Five Eyes'. It became a moral duty - R2P (Responsibility to Protect), as much as the parental duty is to raise their infant child. The handsome, masculine and strong Western Prince Charming has one duty - to emancipate his Eastern Sleeping Beauty. Giving a 'kiss' meant projecting the western physical military presence, Christianity and commerce. ${ }^{10}$ Who was/is the Eastern Sleeping Beauty?

Rudyard Kipling's famous 1899 poem, The White's Man Burden offers some answers while describing the Eastern peoples as 'half-devil and half-child'. "The blame of those ye better / The hate of those ye guard" - Kipling warns and instructs, he describes and invites. In his classic novel of 1847, Tancred - The New Crusade, much celebrated British Prime Minister Benjamin Disraeli claims "A Saxon race, protected by an insular position, has stamped its diligent and methodic character of the century. And when a superior race, with a superior idea to Work and Order, advances, its state will be progressive...All is race!" 11 Quite an intellectual acrobatics for Disraeli himself, who was neither Saxonic nor Christian.

Over the period, western Catholic missionaries constituted one of the most powerful and influential lobbying voices for this civilizing mission. It was of course weaponisation of religion, a notorious misuse for ideological purposes. Same like today, fanatics then and there, were identified, manipulated and further radicalised, to say 'inspired'. In that time Europe, they would have usually got hired as the AGITPROP - an Ideological police by the predatory elites which hid behind the Feudal European states.

Naturally, the justifications were looked upon in any Biblical narrative. E.g. the re-invoking the Genesis story of Noah's three sons, and interpreting it as the 'duty' of Japheth (Europe) to

\footnotetext{
${ }^{9}$ To this end: Inventive, proactive, scientific, rational, disciplined, sell-controlled/self-constraining, sane, sensible, practical, 'mind-oriented', independent, and most of all paternal West. The East, of course, was on the opposite side and inferior: imitative, passive, superstitious, lazy, irrational, spontaneous, insane, emotional, exotic, bodyoriented, dependent, and above all, child-like. Tall, matured 'masculinity' vs. immature and physically underdeveloped 'femininity'. The masculine phallus of military, industry, technology, shipping and trade that is welcomed, if not heartedly invited, to tap and drill the womb-like dwell of resources, while at the same time seeding the ideological semen of 'civilization'.

${ }^{10}$ To this very day, most of the so-called Multinational/Cross-continental Trade Pacts are closer to the capitulation agreements (like those that Britain imposed on China after the Opium Wars) than to any fair, balanced and mutually beneficial commercial accords. Their stipulations are regularly kept away from public eyes. When was the last time you have seen one of them publicly available? No wonder, what a popular language of today calls barriers to trade are in fact the remaining socio-economic sovereign rights and other rarefied checks-and-balance instruments of nation's well-being that these Trade Pacts are derogating. "By hook or by crook" - as the Dutch East India Company formulated it in its XVII century business model moto.

${ }^{11}$ The novel itself is named after the Norman leader of the First European Crusades, that later became the Prince of Galilee, and regent of the satellite Europe's state on the territory of today's Syria and Turkey - Antioch.
} 
absorb Shem (Asians) and enslave and colonise Ham or Canaan (Black Africa and Indianos of America). Amazingly, according to Genesis ch.9, verse 27: "God shall enlarge Japheth and he shall dwell in the tents of Shem, and Canaan shall be his servant". ${ }^{2}$

(While Europe was to face a holocaust of 30-years War among essentially Rimo-Catholic Christians, "Asians commercial and cosmopolitan cities formed a network of hubs spanning numerous multi-ethnic and multilingual empires" - says Parag Khanna.)

The later Protestant revival infused the next wave of Christian missionaries to force this narrative into the matrix of colonisation as 'wilful' implants onto the minds and bodies of overseas peoples. Therefore, James Lorrimer and other architects of that-time political and international legal order divided the world in three segments: civilized White, barbarous Yellow and savage Black. Yellows were 'fallen people', inhabiting a terra infantilis, bound to civilize (what will later evolve into indirect rule, with a social apartheid in place). The area occupied by the Blacks, Redbones and Aborigine was a 'borderless space', terra nullius just to conquer and settle, since the indigenous have no 'birthright' to it (meaning: physical colonisation and direct rule, displacement final solution and genocide).

Even the champion of European rationalism, Max Weber, divinised Europe: "Protestant Reformation and the Protestant ethic it spurred played a key role in facilitating the rise of modern industrial society in Western Europe." Before him, the world's most famous egalitarian, Karl Marx - who sow nations and states not as a statistical reality but as a revolutionary cause - was not so enthusiastic in preaching the proletarian revolution beyond the narrow western world. In Marx's writings, Revolution is reserved for the advanced peoples (that even excludes the eastern European Slavs), and is not meant for those civilisationally behind.

Nevertheless, the unfinished business of 'salvation of the world' came back home; to Europe of the $20^{\text {th }}$ century. Hitler's interpretation of it was: civilized White (Arian) - Central Europe; Yellows (fated for indirect rule, with 'only' social apartheid in place) - Atlantic and Scandinavian Europe; Blacks (whose territory is predestined for a physical colonisation by the superior race upon a decisive final solution and genocide) - all Slavic states of Eastern and Russophone Europe. ${ }^{13}$

Indeed, ever since the $18^{\text {th }}$ century on, European notion that 'civilization' was the monopoly of the West, clearly implied that there is no civilization - and therefore, salvation - outside the western model. ${ }^{14}$ To comply fully with this new myth, the civilizational late comer from the

\footnotetext{
12 "The poor you will always have with you, and you can help them any time you want. But you will not always have me..." /Mark 14:7-9 (NIV) New International Version/ was a Biblical verse, allegedly spelled out by Jesus from Nazareth. It was among most quoted and misused lines - as to justify Europocentrism, exceptionalism and institutionalisation of inequality which then and there have started its global conquest.

${ }^{13}$ To illustrate a centuries-long residual climate of jingoism, later conceptualised and postulated as the European ideology of Biologism, let us quote the III Reich's Biology schoolbook: "The meaning of all life is struggle. Woe to him who sins against this law. Our Führer reminds us: 'He who wants to live must fight, and he who does not want to fight in this world of perpetual struggle does not deserve to live!' (Mein Kampf, p. 317) Hence, 'the world does not exist for cowardly nations'. (Mein Kampf, p. 105)." (For the full quote see appendix: Biology for the Middle School, The 5th Grade Girls; chapter: The Laws of Nature and Humanity, Textbook of 1942)

${ }^{14}$ The Spirit of Laws and other writings of Montesquieu were the most decisive influencers on the French revolutionaries, Jacobins and Napoleon himself. In the hands of French revolutionaries, Buonaparte and later his own nephew - Napoleon III, the Montesquieu's teaching shaped the administrative and legal order of Europe up to this very day. How did Montesquieu see Europe and the world? Well, Montesquieu registered the geographic regularity in prosperity and poverty concentration. His explanation to it was the geography hypothesis: that people in tropical climates tended to be 'lazy and to lack inquisitiveness.' Consequently, they didn't work hard, were not innovative, which ultimately led them to poverty. Montesquieu further speculated that lazy people tended to be
} 
geographic suburbia - actually a remote peninsular northerly extension of the huge Asian continental mass - started calling itself an Old Continent. Historian Toynbee calls it "a secularized version of the primitive Western Christian proposition Nemini salus ...nisi in Ecclesia." See for yourself how much current debates, sparked by the ongoing refugee crisis, follow the above patters. ${ }^{15}$

\section{Triangular economy of othering}

Why does our West so vigilantly promote the so-called international trade all over the place? Answer is at hand; the US President George H.W. Bush clarifies: "No nation on Earth has discovered a way to import the world's goods and services while stopping foreign ideas at the border."16

There is a consensus within the academic community what was the critical factor in redefining the world's periphery - from a sub-permafrost - Europe into the advanced West. Undeniably, it was the extension of its strategic depth westward, to the Americas upon 1492 - a huge continent unreported in the Bible and unknown to Europeans. There is also a consensus over the two factors facilitating the initiation of the age of Grand discoveries. The push effect was the fall of Constantinople, relative decline of the Maghrebian Arabs and the Ottoman technomilitary and demographic threat onto Europe from south and southeast. And, the pull effect was the Ming dynasty inward retreat and to it related dismembering of the superior transoceanic Sino-fleet.

This unleashed the so-called triangular transcontinental trade that incorporated one more previously unknown continent to Europe - (sub-Saharan) Africa. Triangular trade was a brutal instrument imposed by Europeans: Enslaved Africans shipped as cattle to America to dig for gold and silver which was destined for European colonial centres. ${ }^{17}$

(Needleless to say that soon after American continent has been 'discovered', Europeans brutally derogated its indigenous civilisation. Only 100 years later, Americas have suffered loss of $90 \%$ of its total pre-colonial population - a final solution in one of its most effective workings. The same went on in sub-Saharan Africa. Far from being an undiscovered prior to the European conquistas, Africa was for many centuries an integral part of the Afro-Asian

ruled by despots - due to their tropical location - a political phenomenon linked with economic failure, and harsh primitive dictatorships.

15 "Even in the wake of the WWII, Western liberals still had a very hard time applying their supposedly universal values to non-Western people. Thus when the Dutch emerged in 1945 from five years of brutal Nazi occupation, almost the first thing they did was raise an army and send it halfway across the world to reoccupy their former colony of Indonesia. Whereas in 1940 the Dutch gave up their own independence after little more than four days of fighting, they fought for more than four long and bitter years to suppress Indonesian independence. No wonder that many national liberation movements throughout the world placed their hopes on communist Moscow and Beijing rather than on the self-proclaimed champions of liberty in the West." - argues Y.N. Harari (21 Lessons for the $21^{\text {st }}$ Century, page 10).

${ }^{16}$ This deep historical animosity towards the externally induced, forced trade - so foreign to the organic tissue of the nation - is deeply rooted even with the champion of the world's trade of today: China. Its Communist Party leader - not so long ago - Jiang Zemin in his inaugural speech of 1989, defined entrepreneurs as: "self-employed traders and peddlers who cheat, embezzle, bribe and evade taxation."

${ }^{17}$ Historian Patrick Manning estimates that at least 8 million people were exported to Americas as slaves from the West Africa alone between 1700 and 1850. To this number, it has to be added at least $30 \%$ more that died in in the enslaving related struggles all over the Atlantic coast of Africa from a present-day Mali to Angola. Early French colonial records for the western Sudan; a large swath of western Africa (from Senegal via Mali and Burkina Faso, to Niger and Chad) accounted for over $30 \%$ of population being slaves as late as in 1900. Even Liberia founded for freed American slaves - accounted up to one quarter of its population as slaves or in a slavery-like conditions, as late as in 1960s! 
trading and manufacturing system. All that have dramatically changed with the arrival of Europeans. Soon after, they derogated an indigenous socio-political, civilizational and cultural and the demographic structures of Africa beyond the point of reparation.)

Once in Europe, stashes of these precious metals were used to cover massive European deficits created by extensive imports of the cutting-edge technologies, manufactured products, other goods and spices from a that-time superior Asia and the Middle East. Only later, gold and silver will be replaced by the equally powerful but less expensive 'trade facilitators' - iron and opium (guns and drugs). For instance in early 1800s, many British MPs and cabinet ministers had shares in the UK narco-companies. Hence, the Narconomics was introduced and imposed as both a powerful strategic deterrent and as a wealth accumulator. (Eg. Still by the late $19^{\text {th }}$ century, some 40 million mainland Chinese were heavy drugs addicts - roughly $10 \%$ of population.)

The Afro-America yields were so colossal for Atlantic Europe that many scholars assume the so-called Industrial revolution rather as an evolutionary anomaly than a natural sociotechnological process of development, which was primarily pivoting in (Sino-Indian) Asia. ${ }^{18}$ In order to illustrate a magnitude (or to validate the so called Schumpeterian creative destruction claim), let us note a following data: Starting from an early 16th century for consecutive 300 years, $85 \%$ of the world's silver production and $70 \%$ of the world's gold output came from the Americas. For the same period, 2/3 of globally manufactured goods were originating from Asia. Notably, while Europe spent unearned, Asia worked.

Further on, during the 17th, 18th and 19th century the role of Black slavery, slave trading, American Black slave-driven production centres and Negro markets, all significantly contributed to Atlantic Europe's agricultural and industrial 'breakthrough' - as we are celebrating it today. In short, it was a wealth of Americas extracted by the enslaved men-power from Africa, and shipped to Europe under the minimal costs, all that for centuries. ${ }^{19}$

This colossal 'oversea discovery' reinforced Europe's path on defensive modernisation (usage of technology for a narrow geostrategic end) - European empires building became a scientific project and the science evolved into an imperial project. For instance, French Dutch and Britons (the so-called second and third round of colonisers) learned one think from Portuguese and Spaniards (the first round of European colonisers) - nobody wishes to pay taxes but likes to invest. Therefore their colonial expansion was primarily conducted as a corporate undertaking (West India company, East India company, WIC, VOC, Mississippi company, etc.). ${ }^{20}$

Hence, it was a magic vicious circle of scientifically erected empires and imperial capitalism: Credits financed overseas discoveries, discoveries led to colonies, colonies made profits (by imported slaves and rarefied locals), profits built trust in tomorrows, and the trust in this shiny colonial tomorrow was translated into ever more credits for the larger corporate undertakings. Small wonder that the exegesis of (Newtonian science and Smith's) capitalism started blindly to believe in a never-ending and ever-expanding economic growth. The fact that such a 'faith'

\footnotetext{
${ }^{18}$ This of course creates a source of everlasting debates between advocates of historical determinism and those who portray human development as a working of historical contingency. Borrowed from evolutionary biologists, the Path dependence or Contigent path of history is a theory originally developed by economists to explain technology adoption process and industrial r/evolution of the West (allegedly) triggered by an incident or anomaly (biological, genetic, cosmic, geo-morphological, climatic, and then anthropo-cultural, socio-political, etc.).

${ }^{19}$ Even the US Founding Fathers were slaveholders (5 of the 7 principal ones: Benjamin Franklin, John Jay, Thomas Jefferson, James Madison and George Washington).

${ }^{20}$ E.g. the British East India Company controlled Indian sub-continent with its private army of 350,000 soldiers considerably more than the British monarchy had at its own disposal. It was only in 1858 that the UK Crown put India under its direct rule. Dutch took Indonesia from the VOC company after 200 years of its corporate rule over the largest world's archipelago.
} 
contradicts all cosmic laws bothered none in that time Europe - the continent was dizzy and triumphant in its planetary conquest. Le Capitalisme Européen meant expansion - in every possible sense.

Such a rapid shift from a peripheral status to an 'advanced civilization' of course necessitated a complete reconstruction of western identity - furthering the weaponisation of religion for ideological purpose. This acrobatics -in return-caused the rift in Europe and enhanced the Continent's continued split on two spheres: the Eastern/Russophone Europe - closer to and therefore more objective towards the Afroasian realities; and the Western (Atlantic/Scandinavian/Central) Europe, more dismissive, self-centred and ignorant sphere.

While the Atlantic flank progressively developed its commercial and naval power as to economically and demographically project itself beyond the continent, the landlocked Eastern Europe was lagging behind. It stuck in feudalism, and involuntarily constituted a cordon sanitaire - from eastern Baltic to Adriatic Shkoder - against the Islamic Levant/south and the Russo-oriental East.

Gradually, past the $15^{\text {th }}$ century, the idea of 'Western Europe' begun to crystallise as the Ottoman Turks and the Eastern Europeans were imagined and described as barbarians. During the $17^{\text {th }}$ and $18^{\text {th }}$ century as the triangular 'trade' progressed, Atlantic Europe firmly portrayed itself as the prosperous West that borders 'pagan/barbarian' neighbours to its near east, and the 'savage subjects' to its cross-Mediterranean south, overseas west, and the mystical Far East. Consequently, we cannot deny a huge role that the fabricated history as well as the 'scientific' racism and its theories played in a formation and preservation of European identity construct. ${ }^{21}$

The Enlightenment was a definite moment in the reinvention of European identity. The quest came along with the fundamental question who are we, and what is our place in the world? Answering that led on to the systematisation, classification of anthropogeographic inversion and - frankly - to reinvention of the world. From the Renaissance to the Enlightenment, a kind of an intellectual apartheid regime was forming.

(This historical anomaly I usually describe as anthropogeographic inversion in which the periphery asserted itself into the center by periferising that core and managing to present itself as a center. Thus, our current geopolitical and ideological core resides in geographic peripheries of the planet. It is in the hands of late developmental arrivals, such as the UK, Scandinavia, Russia, Canada, the US, Japan, Australia, New Zeeland, Korea, Singapore, South Africa. To achieve and maintain this colossal inversion was impossible without coercion over the extended space and time. Consequently, it necessitated a combination of physical and metaphysical (hard/coercion and soft/attraction) instruments: Physical military presence of the periphery in the center, combined with a tightly guarded narrative and constructed history. How does my anthropogeographic inversion theory correspond with an institutional interpretation of history? Real anthropogeographic peripheries are certainly a new civilizational arrival Interference, intrusion and discontinuity is suffered in a core not on edges. (E.g. It is not centrally positioned Syria, Iraq, Iran or Afghanistan intervening in the geographic peripheries, such as the UK, US, Russia, Canada.) Periphery faster coagulates as it is rarely intruded. Center

\footnotetext{
${ }^{21}$ Explaining the notion of the Bantu Education Act of 1954, one of the chief architects of Apartheid the Dutchborn prof. dr. Hendrik Verwoerd, Prime Minister of South Africa, bluntly spelled out the following in his speech of that year: "The Bantu must be guided to serve his own community in all respects (Bantustan). There is no place for him in the European community above the level of certain forms of labour ... For that reason it is to no avail to him to receive a training which has as its aim absorption in the European community while he cannot and will not be absorbed there." (The State Archives, South Africa, National Library)
} 
itself melts and is melted constantly. In the world of our realities; periphery sends, center absorbs.)

The rise of the West was portrayed as a pure virgin birth as John M. Hobson fairly concluded. Europeans delineated themselves as the, only or the most, progressive subject of the world's history in past, presence and future. At the same time, the Eastern peoples - e.g. Asian as 'the people without history' - were seen as inert, passive and corrosive. ${ }^{22}$ While the Solar system 'became' heliocentric, the sake and fate of our planet turned plain - Europocentric. The world is flat mantra set the stage, turning all beyond Europe into a sanitary corridor, a no-fly-zone.

\section{Ambient, anti-Orient}

"The idea of Europe found its most enduring expression in the confrontation with the Orient in the age of imperialism. It was in the encounter with other civilizations that the identity of Europe was shaped. Europe did not derive its identity from itself but from the formation of a set of global contrasts. In the discourse that sustained this dichotomy of Self and Other, Europe and the Orient became opposite poles in a system of civilizational values which were defined by Europe." - notes Delantry.

Even the English word to determine, position, adapt, adjust, align, identify, conform, direct, steer, navigate or command has an oriental connotation. To find and locate itself opposite to Orient, means to orient oneself.

Feudal Europe had identified itself negatory towards Levant and Islam. It reinvented a historical unity and continuity of Roman Empire (precursor of today's Euro-MED) into an $u s$ them binary categorisation: The peripheral outcast became thus Rome (Western Empire) and the legitimate successor - who outlived its move to Bosporus for over 1.000 years - became 'Byzantium'. ${ }^{23}$ No wonder, tireless binary categorisation is an essential glue and galvaniser.

Clearly, it was an identity heavily resting on insecurity. Proof? An external manifestation of inner insecurity is always aggressive assertiveness.

Is this still alive or even operative? How does it correlate today?

\footnotetext{
${ }^{22}$ Undoubtedly, (western) Europe owes its prosperity to extension of its commerce and colonial expansion. But let us take a closer look: "The profitability of European colonial empires was often built on the destruction of independent polities and indigenous economies around the world, or on the creation of extractive institutions essentially from the ground up, as in the Caribbean islands, where following the almost total collapse of the native populations, Europeans imported African slaves and set up plantations systems. ... We will never know the trajectories of independent city states such as those in the Banda Islands, in Aceh, or in Burma would have been without the European intervention. They may have had their own indigenous Glorious Revolution. But this possibility was removed by the expansion of the Dutch East India Company. ... The British East India Company looted local wealth and took over, and perhaps intensified, the extractive taxation institutions of the Mughal rulers of India - coinciding with the massive contraction of Indian textile industry. The contraction went along with the de-urbanisation and increased poverty. It initiated a long period of reversed development in India. (Find the living parallel with a colossal de-industrialisation and de-population of Eastern Europe past its westernisation from 1989 on - op.aut.) Soon, instead of producing textiles, Indians were buying them from Britain and growing opium for the East India Company to sell in China. ... The Atlantic slave trade repeated the same pattern in Africa. Many African states were turned into war machines intent on capturing and selling slaves to Europeans..." - noted Acemoglu and Robinson (Why Nations Fail, page 271-273).

${ }^{23}$ All until late XVIII century, the word 'Byzantium' was unknown beyond the old-Illyrian name for a small ancient Greek colony of Byzantion. The emperors from Constantinople everybody referred as the Romans. Even the famous codification of Roman law under Iustinianus (Corpus Iuris Civilis) - which lawyers celebrate as the origins of modern law and planetary legal systems - physically took place in Constantinople.
} 


\section{Closing Thoughts}

Europe repeatedly missed to answer to the East and Middle East through a dialogue (instruments) and consensus (institutions) although having both (via CoE; OSCE's MPC; EU's ENP, Barcelona Process, etc.). For the past 28 years, it primarily responded militarily in the MENA (or/and with sanctions, which is also a warfare, a socio-economic one) - via 'Coalitions of the Willing'. However, for a rapidly economically and demographically contracting Europe, the confrontation does not pay off anymore. While practically still yesterday (by the end of WWII), four of the five largest economies were situated in Europe, today only one is not in Asia. None is in Europe. ${ }^{24}$

(Likewise, while the US economy contributed with 54\% of the world output in 1945, today it hardly covers $1 / 3$ of that share. Hence, Americans are not fixing the world any more. They are only managing its decline. Look at their footprint in former Yugoslavia, Afghanistan, Iraq, Libya, Mali, Yemen and Syria.)

The same way the Islam has started as an exclusive Arab monopoly to be soon after taken over (for good) by the Turks, Persians and southeast Asians (who are today far more enhanced), the same way the Modern age has started with Europe, but is today a planetary undertaking that least resides within its originator. Simply, the Old Continent is not a wealthy club anymore. It is a theater with a memory of its wealthy past. Presently, Asia, Africa, Latin Americas are rapidly self-actualising and learning much more from each other than from the West.

And, Europe? Still to this very day, its national institutions are too quickly turning to culture and identity to explain politics, especially at election times. As simple and convenient as it seems, it is not as accurate as such. All across Europe, the governments repeatedly failed at distributive justice, not on culture or behavioural recognition. Thus, the EU has to learn how to deescalate and compromise. Certain identity cannot be put in line only with its geography. It has to respond to other realities as well. This is in the continent's best interest, for the sake of its only viable future. Therefore, it is a high time for the Brussels-headquartered Europe to challenge its rigid socio-political choices, and to evolve in its views and actings - for at home and for abroad.

If we are any serious, let us start by answering the following: Is the so-called Russian expansionism or MENA 'Islamofascism' spontaneous or provoked, is that nascent or only a mirror image of something striking in front of it? And after all, why the indigenous Europe's Muslims (those of the Balkans) and their twins, indigenous Christians of MENA (those of Levant) are now two identically slim shadows on a (bulletholes scarred) wall.

\section{References}

Kabani, R. (1994), Imperial Fictions: Europe's Myths of Orient, Pandora Books

\footnotetext{
${ }^{24}$ The moment of 'liberal truth' always comes from Atlantic. Thus, Ana Palacio who served both sides of Atlantic (as the former Spanish Foreign Minister and the former Senior Vice President of the Washington-based WB) among many others - recently warned the Western Ummah: “After years of handwringing over Obama's strategic "pivot" to Asia, even as Russia was stirring up trouble in Ukraine, Europe is once again a strategic focus for the US. But the deeper message is far less encouraging. The US is acting because its European partners have not. This divergence is troubling. American engagement is necessary to provide momentum, but it is Europe's weight that has served as the critical mass required to move the world's liberal order in a positive direction. From the perspective of the European Union, the latest US security bailout raises the possibility that after more than two decades of growing prominence, Europe will lose its agenda-setting power."
} 
Brading, D.A. (1991), The First America: the Spanish Monarchy, Creole Patriots, and the Liberal State 1492-1867, Cambridge University Press, (pages 80-88)

Losada, A. (1971), The Controversy between Sepúlveda and Las Casas in the Junta of Valladolid, The Northern Illinois University Press, (pages 280-282)

Toynbee, A. J. (1934-61), A Study of History, Vol VII: Universal States; Universal Churches (Oxford University Press 1954) and Vol XII: Reconsiderations (Oxford University Press 1961)

McBrien, R. (2000), Lives of the Popes, Harper San Francisco

Wright, L. (2006), The Looming Tower: Al-Qaeda and the Road to 9/11, First Vintage Books

Kipling, R. (1899), The White Man's Burden: The United States and The Philippine Islands, NY 2(99) McClure's Magazine, (reprint, 1934)

Disraeli, B. (1847), Tancred: Or the New Crusade (Complete), (reprint: Echo Library August 28, 2007)

Khana, P. (2019), The Future is Asian, Simon \& Schuster

III Reich (1942), Biology for the Middle School, The 5th Grade Girls; (Chapter: The Laws of Nature and Humanity), Reichsministerium für Wissenschaft, Erziehung und Volksbildung, Die Reichsdruckerei Berlin (https://research.calvin.edu/german-propagandaarchive/textbk01.htm, accessed as of 181218)

Harari, Y.N. (2018), 21 Lessons for the $21^{\text {st }}$ Century, Penguin-Random House, UK Curtain, P.D. (1984), Cross-Cultural Trade in World History, Cambridge University Press Abu-Lughod, J. L. (1989), Before European Hegemony, Oxford: Oxford University Press Lorimer, J. (1880), The Institutes of Law: a Treatise of the Principles of Jurisprudence as Determined by Nature (2 ed.), Edinburgh - London: William Blackwood \& Sons (retrieved via Archive.org as of 14102018)

Wolf, E. R. (1982), Europe and the People Without History, Berkeley: University of California Press

Hobson, J.M. (2004), The Eastern Origins of Western Civilization, Cambridge University Press

The State Archives, South Africa, National Library (http://libguides.wits.ac.za/LegalDeposit accessed 12122018)

Manning, P. (1996), Slave Trades, 1500-1800: Globalization of Forced Labour (Variorium: Aldershot, UK). Volume 15 of An Expanding World, edited by A. J. Russell-Wood. (ed. and introduction).

Acemoglu, D. and Robinson, J.A. (2012), Why Nations Fail, Crown Business (Random House) NY

Harari, Y.N. (2018), 21 Lessons for the $21^{\text {st }}$ century, Penguin - Random House UK

Delantry, G. (1995), Inventing Europe, London, Macmillan (p.84)

Bajrektarević, A. (2018), From WWI to www., Addleton Academic Publishers, New York

Palacio, A. (2016), Europe on the Sidelines, Project Syndicate (13 Feb 2016, pg.27). 


\section{Appendix}

German Biology Book of 1942 (Biology for the Middle School, For 5th Grade Girls; chapter: The Laws of Nature and Humanity)

We have established that all creatures, plants as well as animals, are in a constant battle for survival. Plants crowd into the area they need to grow. Every plant that fails to secure enough room and light must necessarily die. Every animal that does not secure sufficient territory and guard it against other predators, or lacks the necessary strength and speed or caution and cleverness will fall prey to its enemies... The battle for existence is hard and unforgiving but is the only way to maintain life. This struggle eliminates everything that is unfit for life and selects everything that is able to survive. Mankind, too, is subject to these natural laws, and has won its dominant position through struggle. Our Führer tells us:

He who wants to live must fight, and he who does not want to fight in this world of perpetual struggle does not deserve to live!" (Mein Kampf, p. 317)

Each life form strives to ensure the survival of its species... The number of offspring must be greater than the number of the parents if the species is to survive (law of the larger number of offspring). Each species strives to conquer new territory. Here, too, we can recall the Führer's words: The goal of female education must be to prepare them for motherhood. (Mein Kampf, p. 460)

These natural laws are incontrovertible; Those who resist them will be wiped out. Biology not only tells us about animals and plants, but also shows us the laws we must follow in our lives, and steels our wills to live and fight according to these laws. The meaning of all life is struggle. Woe to him who sins against this law. Our Führer reminds us: The world does not exist for cowardly nations. (Mein Kampf, p. 105) 